\title{
The Compliance Model of Employment Standards Enforcement: An Evidence-based Assessment of its Efficacy in Instances of Wage Theft
}

\author{
Leah F. Vosko \\ John Grundy \\ Eric M Tucker \\ Osgoode Hall Law School of York University, etucker@osgoode.yorku.ca \\ Mark P. Thomas \\ Andrea M. Noack
}

See next page for additional authors
Follow this and additional works at: https://digitalcommons.osgoode.yorku.ca/scholarly_works Snurre Publication: c) (1) $\Theta($
Industrial Relations

This work is licensed under a Creative Commons Attribution-Noncommercial-No Derivative Works 4.0 License.

\section{Repository Citation}

Vosko, Leah F.; Grundy, John; Tucker, Eric M; Thomas, Mark P.; Noack, Andrea M.; Casey, Rebecca; Gellatly, Mary; and Mussell, Jennifer, "The Compliance Model of Employment Standards Enforcement: An Evidence-based Assessment of its Efficacy in Instances of Wage Theft" (2017). Articles \& Book Chapters. 2608.

https://digitalcommons.osgoode.yorku.ca/scholarly_works/2608

This Article is brought to you for free and open access by the Faculty Scholarship at Osgoode Digital Commons. It has been accepted for inclusion in Articles \& Book Chapters by an authorized administrator of Osgoode Digital Commons. 


\section{Authors}

Leah F. Vosko, John Grundy, Eric M Tucker, Mark P. Thomas, Andrea M. Noack, Rebecca Casey, Mary Gellatly, and Jennifer Mussell 


\title{
The Compliance Model of Employment Standards Enforcement: An Evidence-based Assessment of its Efficacy in Instances of Wage Theft
}

\author{
Authors: \\ Leah F. Vosko ${ }^{1}$ \\ John Grundy ${ }^{1}$ \\ Eric Tucker ${ }^{2}$ \\ Mark P. Thomas ${ }^{3}$ \\ Andrea M. Noack ${ }^{4}$ \\ Rebecca Casey ${ }^{1}$ \\ Mary Gellatly ${ }^{5}$ \\ Jennifer Mussell $^{1}$ \\ ${ }^{1}$ Department of Political Science, York University, 4700 Keele Street, Toronto, Ontario, Canada, \\ M3J 1P3 \\ ${ }^{2}$ Osgoode Hall Law School, York University \\ ${ }^{3}$ Department of Sociology, York University \\ ${ }^{4}$ Department of Sociology, Ryerson University, 350 Victoria Street, Toronto, Ontario, Canada, M5B 2K3 \\ ${ }^{5}$ Parkdale Community Legal Services, 1266 Queen Street West, Toronto, Ontario, Canada, M6K 1L3
}

\begin{abstract}
:
This article critically assesses the compliance model of employment standards (ES) enforcement through a study of monetary employment standards violations in Ontario, Canada. The findings suggest that, in contexts where changes to the organization of work deepen insecurity for employees, models of enforcement that emphasize compliance over deterrence are unlikely to effectively prevent or remedy ES violations.
\end{abstract}

Keywords: compliance, employment standards, enforcement, precarious employment, regulation 


\section{Introduction}

Inadequate employment standards (ES) enforcement is a widely acknowledged policy problem across jurisdictions. There is growing recognition that the changing nature of employment fuels precariousness in labour markets, and creates an environment in which employees face greater risk of experiencing ES violations. At the lower end of the labor market, in industries such as cleaning, food services, and accommodation, the increasing prevalence of sub-contracting and outsourcing further intensifies competition and makes ES violations a routine strategy of labor cost containment (Weil 2010, 2014; Milkman, González and Ikeler 2012; Bernhardt, Spiller and Polson 2013). The limited resources available to labor inspectorates (ILO 2006, para. 370) and the dominance of a reactive, complaints-based enforcement system (Weil and Pyles 2006) means that only a small fraction of ES violations are redressed in many jurisdictions.

Some jurisdictions have attempted to buttress workplace protections through the adoption of reforms to their ES enforcement systems (Davidov 2010; Weil 2014; Amengual and Fine 2016). Many of these reforms reflect a 'compliance' model of enforcement, which entails assumptions about the nature of violations and how regulation should be implemented. The compliance model presumes violations to be largely exceptional rather than normal behavior and due primarily to a lack of knowledge among regulated parties (Gunningham 2010). It casts regulated parties as interested in legal compliance, and therefore privileges soft-touch modes of regulation. The compliance model's conception of violations and the behavior of regulated parties diverges sharply from a deterrence model of regulation, which views non-compliance with the law as often intentional behavior driven by a cost-benefit calculus and warranting punishment (Pearce and Tombs 1990). 
This article challenges the theoretical assumptions of the compliance model in the context of ES enforcement through a case study of monetary ES violations ${ }^{1}$ - or what is known colloquially as "wage theft" - in Ontario, Canada. As in other jurisdictions, the Government of Ontario's recent efforts to improve ES enforcement draw heavily from the compliance paradigm. Among other changes, starting in the mid-2000s the Ontario Ministry of Labour (MOL) produced more promotional material for employers and employees on their respective rights and responsibilities under the Employment Standards Act (ESA) and made greater use of self-help and settlements to expedite the resolution of ES problems. Yet an analysis of a previously unavailable source of administrative data on ES enforcement in the province demonstrates how the compliance framework alone is a deficient model on which to base reforms to workplace regulation. Indeed, the empirical findings offered herein reveal a disjuncture between central premises of the compliance model and employees' experience of monetary ES violations. Contrary to the compliance model's emphasis on empowered and cooperative self-regulation, ES complaint data suggest that imbalances in workplace power constrain the exercise of employee voice and make seeking legal redress a risky venture for employees. The characteristics of the ES complaints that are investigated and validated by the MOL also suggest that monetary violations of ES are frequently not the result of ignorance or incompetence on the part of employers. Rather, the relatively large median dollar value associated with monetary violations, and the low rates of recovery of MOL-issued monetary orders, point toward the intentionality of violations and employer recalcitrance in the enforcement process. Findings from this Ontario-based case study thereby suggest that, in contexts where changes to the organization of work deepen insecurity for employees and augment employer power, models of enforcement that emphasize compliance over deterrence are unlikely to effectively prevent or remedy ES violations and can 
exacerbate regulatory degradation (Tombs and Whyte 2013). Effective workplace regulation that helps pre-empt ES violations requires enforcement models that start from a dual recognition of workplace power imbalances and the likelihood that many violations are intentional.

The remainder of this article proceeds in three parts. Section one defines the features of a compliance model of enforcement and the related notion of the enforcement pyramid, contrasting more deterrence oriented approaches. Turning to the empirical analysis, section two describes the dominance of a compliance orientation in the enforcement of the Ontario ESA with attention to the case of monetary ES violations. Against this backdrop, it provides a profile of the reporting behaviour of complainants and features of complaints that run counter to the image of mutual interest and cooperation between employers and employees and the unintentionality of violations. By way of conclusion, section three asserts that a model of ES monetary violations that assumes they are frequently intentional activity is a necessary starting point for improved enforcement.

Before proceeding, a note on methods and sources is warranted. As the chief administrative data set retained under the provincial ESA, and the principal data source for this paper, the MOL's Employment Standards Information System (ESIS) contains information on all complaints submitted and their outcomes, violations detected, inspections conducted, settlements, the use of enforcement mechanisms, wage recovery, and Ontario Labour Relations Board Reviews (commonly known as Appeals). A central feature of the ESIS is that it provides a nearly-complete census of Ontario's ES enforcement activities and their outcomes that is not otherwise publically available. But while it captures a variety of information related to the ESA and its enforcement, the ESIS is primarily a tracking and record-keeping system. Like other administrative data, it has several limitations: first and foremost, as an indicator of reactive 
enforcement practices, it only captures the experiences of those who are successful in entering the administrative system. The vast majority of employees who experience a violation do not complain; hence, they are not captured in administrative data (Weil and Pyles 2006; Noack, Vosko and Grundy 2015). Second, as it was not designed for research purposes, ESIS data have not undergone the same quality control and data verification processes as survey data from large statistical agencies. Thus, the dataset includes inconsistencies, some of which appear to result from discrepancies in complainants' reporting (such as complainants who indicate that they are "still working" for an "out of business" employer), and some of which appear to occur when one aspect of the database is updated, but additional information remains in the system (such as when a complaint is listed as being "denied" but also has an Order to Pay Wages issued for it). ${ }^{2}$ In many instances, it is not possible to verify which information is correct; for this reason, in the ensuing analysis, the general approach is to let these inconsistencies persist.

\section{The Dominance of Compliance in Employment Standards Enforcement}

For as long as there has been wage labor, there have been unpaid wage claims. The reason lies in the near universal practice of paying employees in arrears - after they have provided service. This makes wage workers (i.e., employees) their employers' creditors in between pay days, and like all creditors they run the risk of not being paid. However, wage employees are not like ordinary creditors in many ways. Unlike commercial creditors, they do not have the ability to run credit checks or to diversify credit risks among a number of different employers. But, more fundamentally, they stand in a relationship of asymmetrical dependency with their employers (Wright 2015).

Historically, most wage protection laws aimed to facilitate wage recovery and thus created legal mechanisms to enhance wage workers' ability to recover what they were owed. 
These are compliance measures in the sense that they aim to ensure that employers fulfil their contractual obligations. There has been much less appetite to deploy deterrence measures that punish employers for their failure to pay wages in the first place by making non-payment a regulatory offense or a crime. ${ }^{3}$ Yet questions relating to the use of compliance and deterrence measures have been and remain a matter of public concern. For instance, in Canada, from 1935 to 1954 , it was a crime to intentionally not pay the minimum wage established by a law of Canada (S.C. 1935, c. 56; Tucker 2016). Most recently, these issues have been foregrounded by campaigns that target "wage theft" by employers (e.g., Judson and Francisco-McGuire 2012).

There is also a longstanding debate in the legal literature about the use of compliance and deterrence approaches to regulatory enforcement (Reiss 1984; Gunningham 2010: Reynaers and Parrado 2016). Compliance and deterrence theories are based on fundamentally different assumptions about the causes of legal violations and their normative significance. Applied to questions of workplace regulation, deterrence theory is premised on the idea that a substantial proportion of labor standards violations, including non-payment of wages, are caused by the intentional actions of employers who have determined they are better off not complying with their legal obligations. Therefore, the goal of the law should be to alter employers' behavior by raising the risk of being caught and/or increasing the penalties for breaching the law. An emphasis on this goal will generate specific and general deterrence thereby shaping the future behavior of both the employer found to be in violation and of employers generally (Pearce and Tombs 1990; Tombs and Whyte 2013a). Moreover, deterrence theorists make the normative claim that wage violations should not be treated as a private problem resolved by compensating the individual for her or his loss, but rather should be viewed as a serious social hazard that not only harms individual employees and their dependents but that also contributes to a climate in 
which processes of evasion, erosion and abandonment could lead to a gloves-off labor market in which public decency is sacrificed to the drive to maximize profits at any cost (Almond and Colover 2012).

In contrast, compliance theory is premised on the idea that violations, including presumably breaches of the duty to pay, are the result of employer ignorance and incompetence rather than intentional behavior. The primary strategy for improving employers' performance of their legal obligations, therefore, is to provide information and compliance assistance on the assumption that most employers will respond by becoming law abiding citizens. Indeed, in particularly optimistic versions of compliance theory, employers will go beyond the minimum that is required and a culture of compliance will foster even higher standards of behavior. The few bad apples that do not respond to compliance measures will then be isolated and subject to deterrence measures. This approach is seen to be particularly appropriate in the employment context, where regulations apply to individuals and corporations engaged in beneficial economic activities. As a result, non-payment of wages is principally framed as an instrumental problem rather than a moral one for which punishment is merited (Almond and Colover 2012). Figure 1 below provides a somewhat simplified but nevertheless accurate account of key differences between deterrence and compliance approaches to enforcement. 


\section{Figure 1: Features of Deterrence and Compliance Regulatory Paradigms}

\begin{tabular}{|c|c|c|}
\hline & Deterrence & Compliance \\
\hline Subjects of Regulation & Rational Calculator & $\begin{array}{l}\text { Ignorant or Incompetent } \\
\text { Citizen }\end{array}$ \\
\hline Goal & Alter Cost-Benefit Analysis & Educate \\
\hline Means & $\begin{array}{l}\text { Raise Risk of } \\
\text { Detection/Increase Penalty }\end{array}$ & $\begin{array}{l}\text { Provide Information and } \\
\text { Compliance Assistance }\end{array}$ \\
\hline Effects & $\begin{array}{l}\text { Specific and General } \\
\text { Deterrence }\end{array}$ & $\begin{array}{l}\text { Promote Culture of } \\
\text { Compliance }\end{array}$ \\
\hline Nature of Harm Caused & Serious Social Harms & $\begin{array}{l}\text { Remediable Harms } \\
\text { Incidental to Beneficial } \\
\text { Activity }\end{array}$ \\
\hline
\end{tabular}

Ayres and Braithwaite's (1992) responsive regulation approach aimed to transcend the debate between those who favor stronger state regulation (deterrence) and those who favor more selfregulation (compliance). Their key idea is that rather than needing to choose between compliance and deterrence, both elements can be combined effectively in a way that is responsive to the regulatory context. The model developed by these authors, and for which responsive regulation is best known, is the enforcement pyramid which starts with persuasion at the base and provides that if and only if this fails to secure compliance, regulators should escalate to the next enforcement action that has more bite and if, and only if, this action fails escalate again, eventually reaching the most serious sanctions with the greatest deterrence effects. The assumption of the pyramid is that most regulatory activity will take place at the bottom and that fewer and fewer regulatory interventions will be necessary as regulatory interventions become more forceful. The hammer of deterrence is necessary, but should largely remain hidden. 
The enforcement pyramid and its preference for and heavy reliance on compliance measures assume that violations are exceptional, the result of ignorance or incompetence, and that most employers are predisposed to obey the law. While Ayres and Braithwaite insist that the enforcement pyramid is designed to address both those who are inclined to virtue and those who are not, they embrace the republican idea that "most citizens comply with the law most of the time because it seems wrong to them to break the law" (Ayres and Braithwaite 1992, 94). The model is rooted in Third Way political discourse which imagines that antagonistic social relations can be transcended by civic republicanism's emphasis on the empowering potential of dialogue and participation (Mascini 2012; Tombs and Whyte 2013). The model of the enforcement pyramid further entails transposition from citizen to corporation, which underlies the "moralization of the corporation" (Shamir 2010), without making any reference to the political economic context in which it operates.

The omission of political economic context is critical, especially when neo-liberal modes of governance weaken state capacity to regulate against the interests of profit-maximizing corporations, and undermine the ability of workers to act collectively to defend their interests within the corporation (Harvey 2005; Tombs and Whyte 2010). The impact of such transformations on the changing nature of employment provides grounds to question some of the tenets of the compliance model for ES enforcement (Davidov 2010; Tucker 2013; Dickens 2014; Vosko, Grundy and Thomas 2016). Weil (2014) demonstrates that in many sectors of the U.S. economy, employment relations have been transformed through a process of fissuring which leads businesses to avoid having employees through contracting out, franchising and the use of extended supply chains. The result is that employment is being pushed into increasingly competitive environments where employers are under enormous pressure to reduce costs, and 
since labor costs often comprise a considerable portion of total costs in these industries the incentive to violate the law grows, resulting in a greater propensity to engage in intentionally evasive actions. ${ }^{4}$ Other researchers document the spread of precarious employment in Ontario, which parallels the conditions described by Weil in the United States, highlighting asymmetrical power relations resulting from the loss of security that employees experience (Lewchuk et al. 2015). Such asymmetries have substantial implications for employees' willingness/ability to act as their own advocates, let alone on behalf of the interests of their co-workers, particularly in the context of non-unionized workplaces (Gray 2009; Almond and Gray, Accepted Article). Even though ES legislation typically protects employees against reprisals for seeking to enforce their rights, under precarious employment conditions fear of retaliation is likely to grow and thus undermines the culture needed to support a reliance on compliance measures as the principal means of ES enforcement.

The analysis below critically interrogates the assumptions of the compliance model through a case study of ES enforcement in Ontario drawing on the MOL's administrative data. While administrative data on ES complaints do not provide a direct measure of ES violations on the ground, as complaints represent only a small fraction of overall violations, the data can provide insight into certain characteristics of complainants and the claims they make, and the behavior of employers once they enter into the enforcement process. Through an analysis of data from complaints submitted in the 2014/15 fiscal year ${ }^{5}$ (unless otherwise indicated below), this inquiry demonstrates the fallacy of several premises of a compliance framework. The analysis focuses primarily on complainants who received entitlements for claims related to unpaid wages, overtime pay, vacation pay/time, public holidays or public holiday pay, deductions from wages, minimum wage, termination pay and severance pay. When focusing on settlements, 
complainants who submitted claims for unpaid wages, overtime pay, vacation pay/time, public holidays or public holiday pay, deductions from wages, minimum wage, termination pay and severance pay are examined. Results reveal how the situation of aggrieved employees, and the common features of monetary ES violations, are at odds with narratives of empowered selfadvocacy among employees and the unintentionality of workplace violations.

\section{Compliance in the Enforcement of Ontario's Employment Standards Act, 2000}

For the majority of employees in Ontario, the ESA establishes minimum standards in areas including wages, hours of work, overtime pay, vacations, public holidays, and termination and severance. In principle, the legislation was designed to provide regulatory protection for employees with little bargaining power and particularly for those not represented by a union. The enforcement of the ESA has long been oriented around a compliance-based approach to workplace regulation. The bulk of enforcement resources go into the operation of an administrative process for wage recovery. ${ }^{6}$ Employees can complain to the MOL that their rights under the Act have been violated (s. 96). If the complainant has taken the steps specified as a condition of filing a complaint (s. 96.1), the Director may assign the complaint to an Employment Standards Officer (ESO) who has the power to conduct an investigation (ss. 86, 91). If the ESO finds a violation, the officer has multiple powers. In terms of wage recovery, the ESO can facilitate a settlement (s. 112), solicit a voluntary payment from the employer, or issue an order to pay the amount owing (s. 103), which must also include an order to pay administrative costs. There are additional powers to recover the wages if they are not paid by the employer, including issuing orders to pay to corporate directors (s. 106) or related employers (s. 4). These are all compliance measures in that they are limited to enforcing the statutory obligation to pay wages without imposing any penalty for having failed to do so. 
The ESA also provides for deterrence measures. An employer that contravenes the Act, including non-payment of wages, commits a regulatory offense (s. 132) and becomes liable on conviction to a fine or imprisonment. It is also a regulatory offense to fail to comply with an order to pay wages, but it is important remember that non-payment is itself an offense. The procedures for prosecuting regulatory offenses are outlined under the Provincial Offences Act (S.O. 1990, c. P.33), which provides for tickets (R.R.O. 1990, Reg. 950) or formal prosecutions. There is also a lesser deterrence measure available under the ESA, a Notice of Contravention (s. 113), but it is not available for wage violations (O.Reg. 289/01).

Reforms to the enforcement process in the 2010s that emphasized conciliatory regulation and self-help/self-representation further tilted Ontario's ES enforcement regime toward the compliance model. For example, changes to the ESA in 2010 introduced a requirement for complainants to attempt to resolve their concern directly with their employer prior to an intervention by the MOL. Subsequent to this change, part of the MOL's determination about whether a complaint would be investigated include whether or not an employee sufficiently attempts to first approach their employer with their concerns. Operating during the period of this study, the adoption of this initial step entrenched the MOL's emphasis on 'self-reliance' as the primary mechanism through which ES complaints are to be resolved.

Simultaneous reforms to the ESA introduced an additional avenue for employees and employers to resolve claims through facilitated settlements. Previously only non-facilitated settlements could be reached between employees and employers. Non-facilitated settlements require that a written agreement be provided to the ESO outlining the terms of the settlement, and the claim is then closed without an admission of wrongdoing and without requiring the ESO to assess whether an ES violation has occurred. Facilitated settlements involve the ESO as a 
settlement facilitator between the employee and the employer. According to the MOL's guidelines, the ESO is involved in "[h]elping parties understand the strengths and weaknesses of their cases; providing parties with information on how the ESA applies to their cases; [and] helping parties to frame their position and communicate with each other" (MOL undated: 3 ). The introduction of a new form of settlement and the requirement for attempted self-resolution at the outset of the claim process reinforce the MOL's tendency to approach ES regulation in a manner that assumes employer and employee responsibility for ES compliance. The emphasis now placed on settlements reflects key assumptions of the compliance framework: that regulated parties have the capacity to represent their interests effectively, and that most employers, if provided the correct information, will comply with the legislation (Thomas 2009).

\section{a. Complainants' Reporting Behavior: Indications of Workplace Power-Imbalances and the Risk of Exercising Voice}

ESIS data on the characteristics of complainants paint a picture that runs counter to the compliance model's assumption of empowered self-representation and conciliatory and nonantagonistic regulation. They indicate that power imbalances in the workplace impede the exercise of employee voice. Only a small minority of complaints with wage related violations, consistently less than 1 in 10 each year, are filed by individuals who are on the job they are complaining about. Such low rates of complaints from individuals in the job they are complaining about appear to be longstanding, as the 2004 Annual Report of the Auditor General of Ontario found a similar rate of on-the-job complaints (10\%). These low rates suggest that complainants likely perceive filing a complaint as a risky venture.

As intended by the self-resolution requirement introduced into the ESA in 2010, the vast majority (85\%) of those who made complaints with a monetary component in the 2014/15 year reported that they contacted or tried to contact their employer with their concerns. Among those 
who entered into the formal complaints process, about one-third of those who contacted their employers (32\%) report that their employer refused to do anything, and $18 \%$ report that their employer did not respond to their concerns. Among those who did not contact or attempt to contact their employers about their concerns, the most frequently cited reason for non-contact was fear. This concern was raised by almost half $(41 \%)$ of those who did not attempt to get in touch with their employer. It is likely that for many employees who experience monetary violations of ES, fear is a major impediment to contacting their employer and/or entering into the formal ES complaints system.

The central risk employees face if they speak out about workplace conditions is reprisal from employers, which can entail receiving undesirable assignments and schedules, being subject to harassment from management or co-workers, or being terminated, among other things. Fear of reprisal is a longstanding factor in discouraging employees from initiating ES complaints against their current employer with the MOL (Fudge 1991; Employment Standards Working Group 1996). The risks of reprisal after complaining about a violation are shaped by the social location of claimants. For example, employees participating in Canada's Temporary Foreign Worker Program are tied to a single employer, and can face non-renewal of their employment or potentially deportation if they seek to access the ES complaints system (Faraday 2014). ESIS data indicate that reprisal claims filed by complainants are increasing. Whereas in 2008/09, reprisal claims were only included in $4 \%$ of all complaints with wage-theft violations, the proportion of complaints that have a reprisal component have grown steadily across time, increasing to $6 \%$ in $2010 / 11$ and $9 \%$ in $2014 / 15$. The increase in the proportion of complaints with reprisal claims provides additional evidence to suggest that self-help requirement exacerbates the 
risks of filing an ES complaint. Reprisal claims are also more common among complainants still working for their employer at the time that they make a complaint.

The MOL's own data on complainants' reporting activity thus demonstrate that claimsmaking activities are inevitably related to power imbalances in the workplace, which are welldocumented in studies on ES enforcement (Ruckelshaus 2008; Alexander 2013; Tucker 2013; Griffith 2015). There are strong grounds to suggest that the self-help requirement discourages some aggrieved employees from filing a complaint. This conclusion is supported by the recent, notable decrease in the share of non-unionized employees in Ontario who file ES complaints. Before the introduction of the self-help requirement, the number of ES complaints received by the MOL increased, and then steadily declined after the requirement's introduction (see Figure 2). Whereas the decline levelled off starting in 2012/13, the overall downward trend after 2010 is notable given the increase in the absolute number of non-unionized employees in Ontario during this period. At its peak in 2008/09, the MOL received roughly one complaint per every 175 nonunionized employees in the province, whereas in 2014/15, it received roughly one complaint per every 285 non-unionized employees. 
Figure 2: Employment Standards Complaints Received ${ }^{7}$

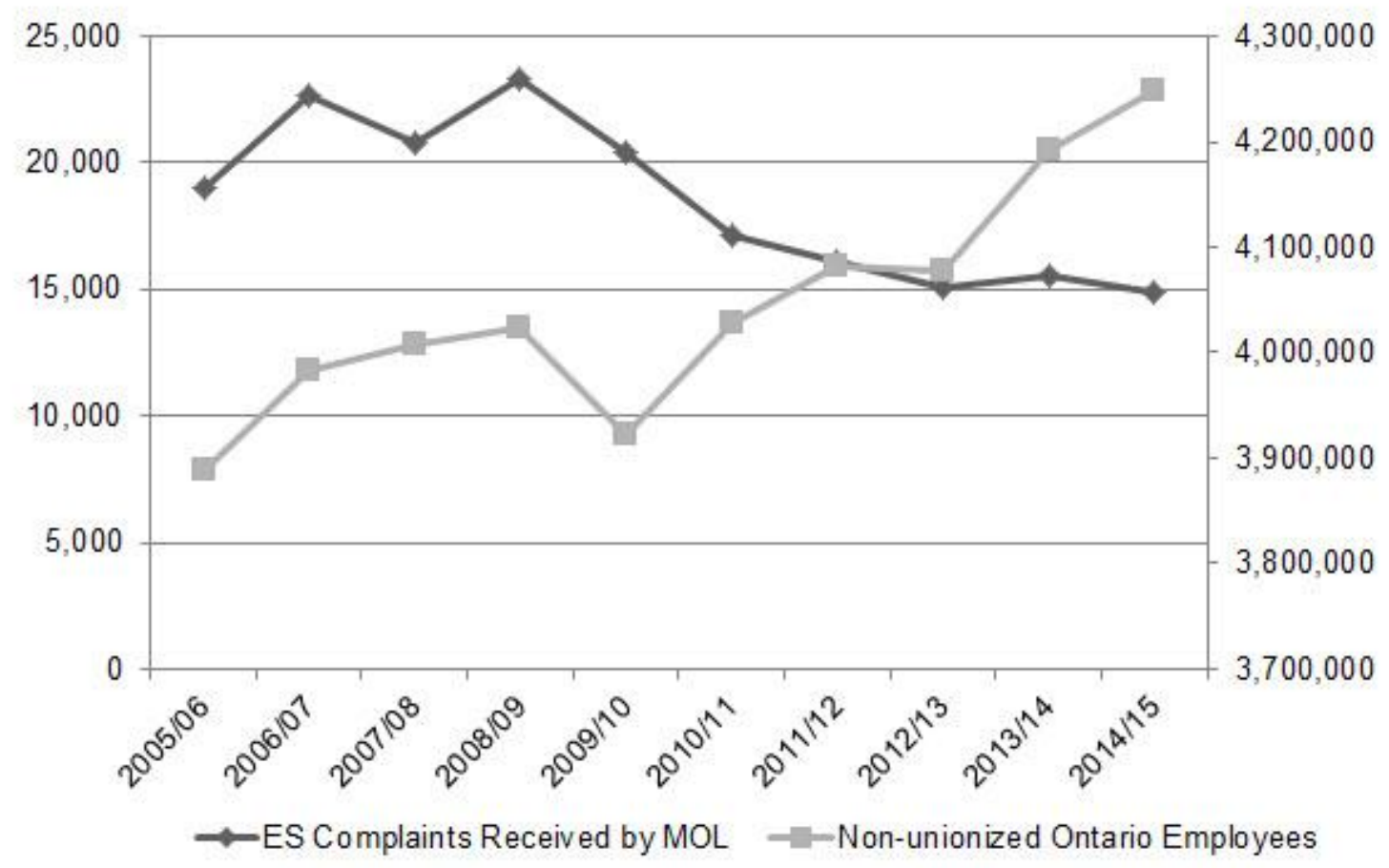

ESIS data on the industrial location of complainants further counters the compliance framework's account of the unintentionality of violation. The data point to the relevance of economic considerations in employers' violations of ES. Employees who make monetary complaints are concentrated in specific industrial sectors (see Figure 3). In 2014/15, the sectors of accommodation and food services, construction, and management, administration and other support services generated monetary ES complaints at a rate disproportionate to their size. The high absolute and relative number of complaints from employees in the accommodation and food services industry is particularly notable. The majority of complainants from this industry (54\%) are employed in full-service restaurants, and a quarter (25\%) are found in limited service eating places, such as fast food restaurants. The next most overrepresented industry among monetary ES complaints is construction. The largest number of complaints from the construction industry come from residential building construction and all other speciality trade contractors. The third 
most overrepresented industry grouping is referred to as management, administrative and other support services. This category includes call centres, temporary staffing agencies, building and grounds services, cleaning services, security services, waste disposal services, among others. The largest number of complainants from the support services industry comes from janitorial services, landscaping services, security guards and patrol services, and telephone call centers.

Figure 3: Industry of Validated Monetary Employment Standards Complaints ${ }^{8}(2014 / 15)$

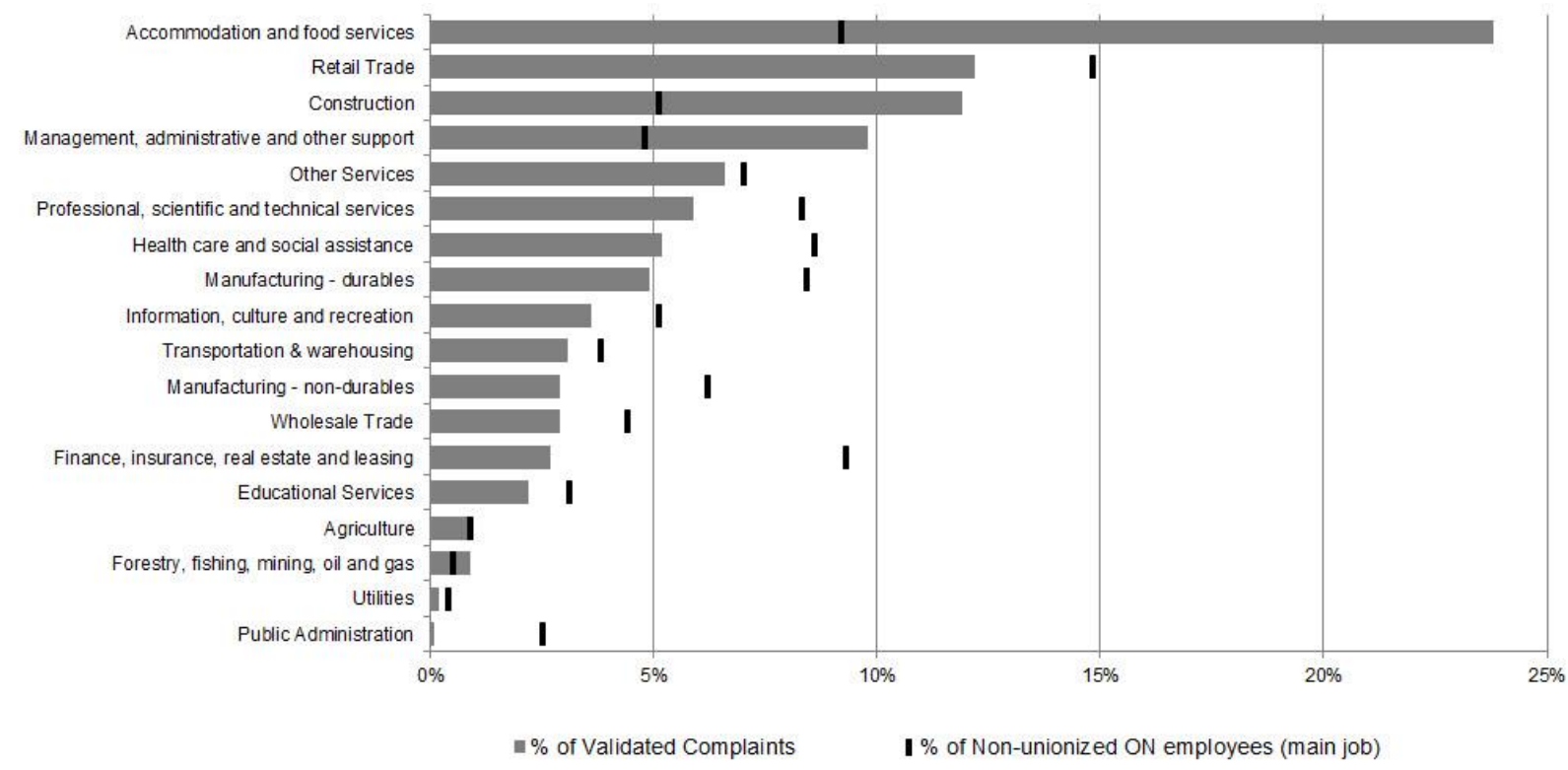

It is impossible to decipher the prevalence of violations at the industry level with administrative data. Industries characterized by high rates of violations may generate relatively low levels of complaints, and vice versa (Weil and Pyles 2006). The decision to file (or not file) a complaint is related in part to the culture of an industry which shapes what violations become normalized and routinely disregarded by workers, and those which are considered inappropriate and requiring redress. However, the concentration of monetary ES complainants in accommodation and food services, support services and the construction industry is consistent with findings in other jurisdictions. In the United States, these industries have been identified as priorities for the Federal Department of Labor's Strategic Enforcement initiatives which aim to direct resources to 
industries where violations are most likely to occur (Weil 2010, 10). Whereas in the manufacturing industry, a dominant strategy of labor cost reduction is the relocation of production to jurisdictions with less stringent regulations, employers in non-mobile service industries pursue lower labor costs through what Weil (2010) calls fissuring, which entails the use of sub-contracting and outsourcing. A long-time practice in the construction industry, and now a central feature of business support services and the accommodation industry, the offloading of labor costs onto smaller entities and labor intermediaries generates intensive pressures and opportunities for employers to violate ES (Estlund, 2005; Weil, 2010; Bernhardt, Spiller and Polson 2013; Fine, 2013). The industrial location of many complainants in highly fissured industries suggests that ES violations are being driven by broader economic factors including industrial restructuring and precarious employment rather than simply ignorance or incompetence on the part of employers.

Complainants also overwhelmingly tend to have worked in smaller companies (see Figure 4). ${ }^{9}$ Employees in small firms of fewer than 20 employees are grossly over represented among complainants. Whereas only $23 \%$ of employees in Ontario work for firms of this size, they account for a majority of monetary ES complaints at $62 \%$. Almost forty percent (39\%) of complaints come from those working in firms that employ 6-19 people - typically small or startup companies that go beyond an individual entrepreneur. It could be that small firms lack the HR capacities to ensure full compliance, thus supporting the compliance narrative. But, given previous research that demonstrates how precarious employment is more prevalent in small workplaces (Noack and Vosko 2011), due to their vulnerability to instabilities associated with economic fluctuations, ${ }^{10}$ it is more plausible that small firms are more likely to transgress workplace standards as a labor cost reduction strategy. Complaints related to small firms are 
more likely to include claims for unpaid wages, reflecting the financial constraints of small firms and their greater likelihood of having employees in arrears.

Figure 4: Firm Size of Validated Monetary Employment Standards Complaints (2014/15)

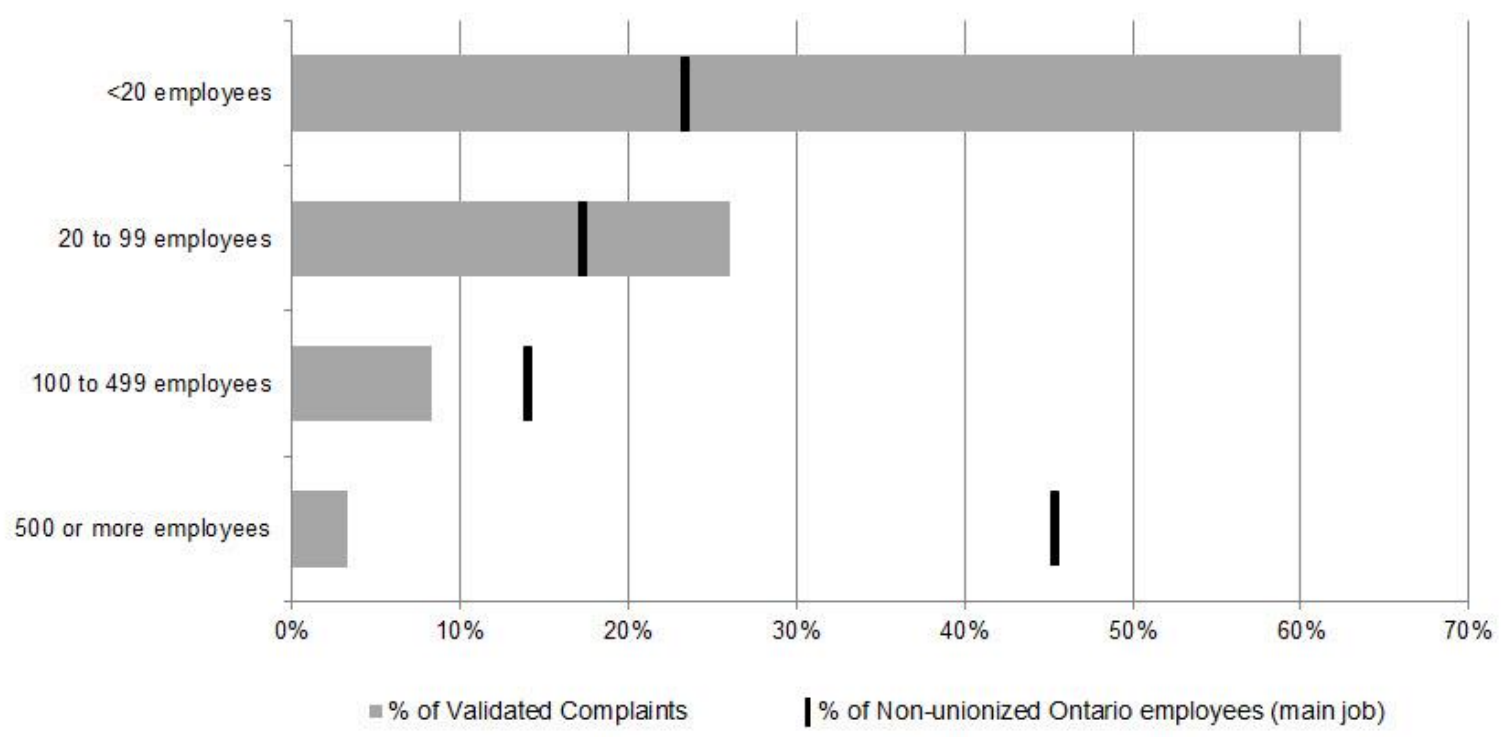

In sum, the model of violations inherent in the compliance framework does not reflect important aspects of complainants' experience of ES violations in Ontario. Contrary to assumptions of effective self-representation and the viability of conciliatory modes of claims resolution in the compliance model, ESIS data point to the existence of workplace power imbalances that discourage claims making, and limit effective self-regulation on the part of employees. The data indicate employees' overwhelming tendency to avoid filing complaints while still on the job, as well as their perception or experience of the risks of reprisal associated with filing a complaint. Claims data further demonstrate the concentration of complainants in industries and firms characterized by high rates of precarious employment. These characteristics of ES complaints belie the assumption that many violations are unintentional, an assumption that is central to the compliance-based model's prescriptions for education and awareness initiatives. 


\section{b. The Prevalence of Egregious and Unresolved Monetary Complaints ${ }^{11}$}

While administrative data do not allow for determining the most common types of violations that occur on the ground, they do permit a number of observations regarding complaints that cast further doubt on the compliance model's narrative of violations as largely unintentional and amenable to voluntarist solutions. The most common type of monetary claim submitted to the MOL is for unpaid wages, either alone or in combination with other claims (see Figure 5). ${ }^{12}$ Unpaid wage claims are included in $60 \%$ of monetary wage-theft complaints. A similar trend appears among validated complaints, over half (52\%) of which include a claim for unpaid wages. The prevalence of claims for unpaid wages is noteworthy because, among the various standards that can be claimed, unpaid wages are unlikely to be simply attributable to incompetence or a lack of information on the part of the employer. The likelihood that unpaid wages are the result of an employer's intentional practice is underscored by their size. The median dollar value of validated claims for unpaid wages is $\$ 793$. These unpaid wage entitlements represent a substantial portion of weekly or monthly earnings for low wage earners, and suggest that monetary violations are typically more egregious than is acknowledged in a compliance framework that stresses the unintentionality of violation. 


\section{Figure 5: Prevalence of Employment Standards Claims among Validated Monetary Complaints (2014/15)}

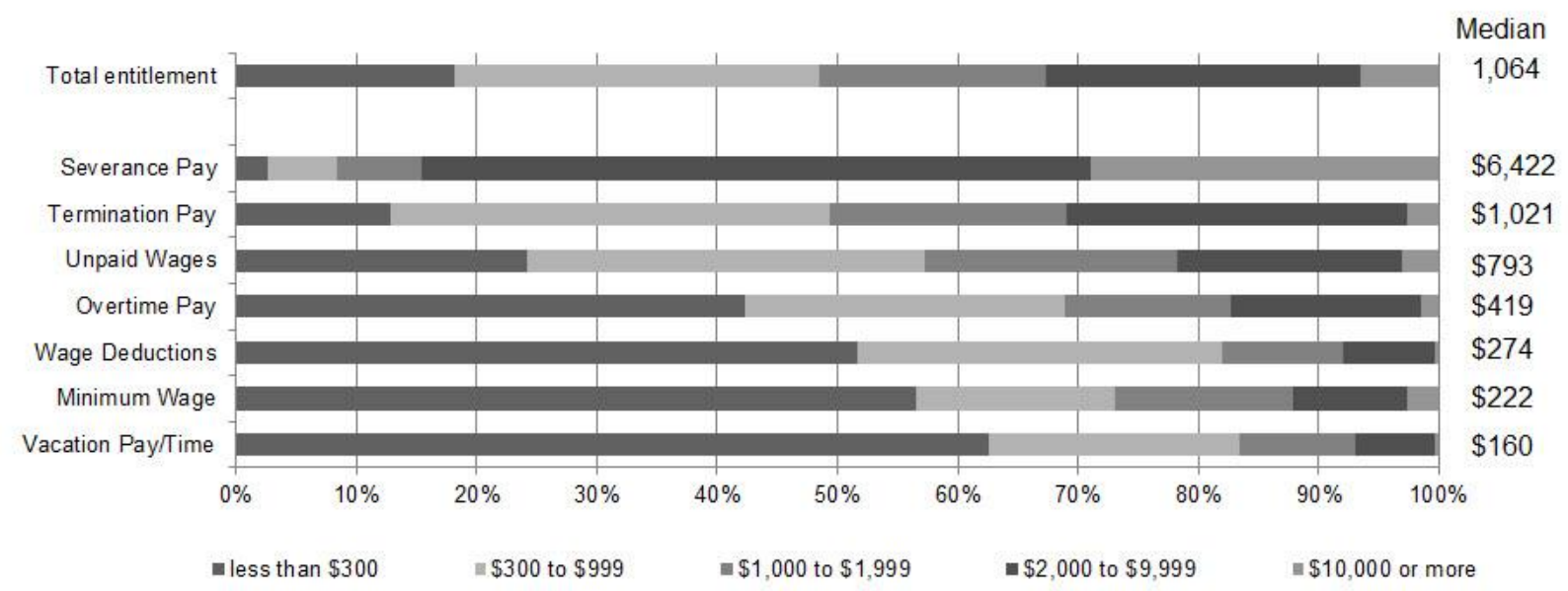

A comparison of the median dollar value of complaints resolved via voluntary compliance versus those for which compliance is ordered is also telling. In half of complaints with a monetary entitlement (50\%), the employer voluntary complies with the ESO's finding and pays the entitlement, an outcome consistent with the non-antagonistic modes of redress emphasized under the compliance model. Complaints that are closed through voluntary compliance tend to be for lower total claim values than those with a monetary order. Among complaints closed through voluntary compliance, the median total entitlement is $\$ 603$. In contrast, among complaints where compliance is ordered, the median total entitlement is $\$ 1,860$. Clearly, employers are most likely to voluntarily comply with lower-value entitlements, a fact which further indicates the role of business considerations in shaping employers' decisions to cooperate in the enforcement process.

If voluntary compliance is not achieved, the ESO will normally issue a monetary order in the form of an Order to Pay Wages or an Order to Compensate and/or Reinstate. Recovery rates for monetary orders are disturbingly low. When all complaints with a monetary order during the period between 2009/10 and 2014/15 are considered, only 39\% were fully satisfied, $7 \%$ were partially satisfied, and 54\% were not satisfied. Outstanding orders are sent to collections, and of 
those, only one in five (22\%) are subsequently fully satisfied. In the case of monetary orders, partial or non-cooperation on the part of employers is the norm rather than the exception. It is important to note here that businesses that are bankrupt or in receivership are not issued an Order to Pay Wages or an Order to Compensate and/or Reinstate. Recovery rates among these types of businesses are much lower than the rates presented above. The MOL's limited success in recovering money for complainants further belies the assumption of cooperation in the compliance framework.

Another possible outcome for complaints is a settlement. Employers and employees can arrive at a settlement, with or without the ESO acting as a settlement facilitator. Not surprisingly, the larger the submitted total claim amount, the less likely that it will be settled for $100 \%$ or more of that amount. Facilitated settlements, which are generally used for higher-value claims, lead to inferior outcomes for workers than non-facilitated settlements (see Figure 6). In 34\% of cases, facilitated settlements are settled for less than half of an employee's total initial claim, while almost $25 \%$ of non-facilitated settlements are settled for less than half of an employee's total initial claim, suggesting that the involvement of the ESO produces a resolution that is overall less favorable to the complainant. These results lend credence to concerns voiced by analysts when complianceoriented reforms were introduced - that the adoption of facilitated settlements would introduce new pressures for complainants to accept settlements below their legal entitlements. 


\section{Figure 6: Settlement Outcomes for Monetary ES Complaints ${ }^{13}(2014 / 15)$}

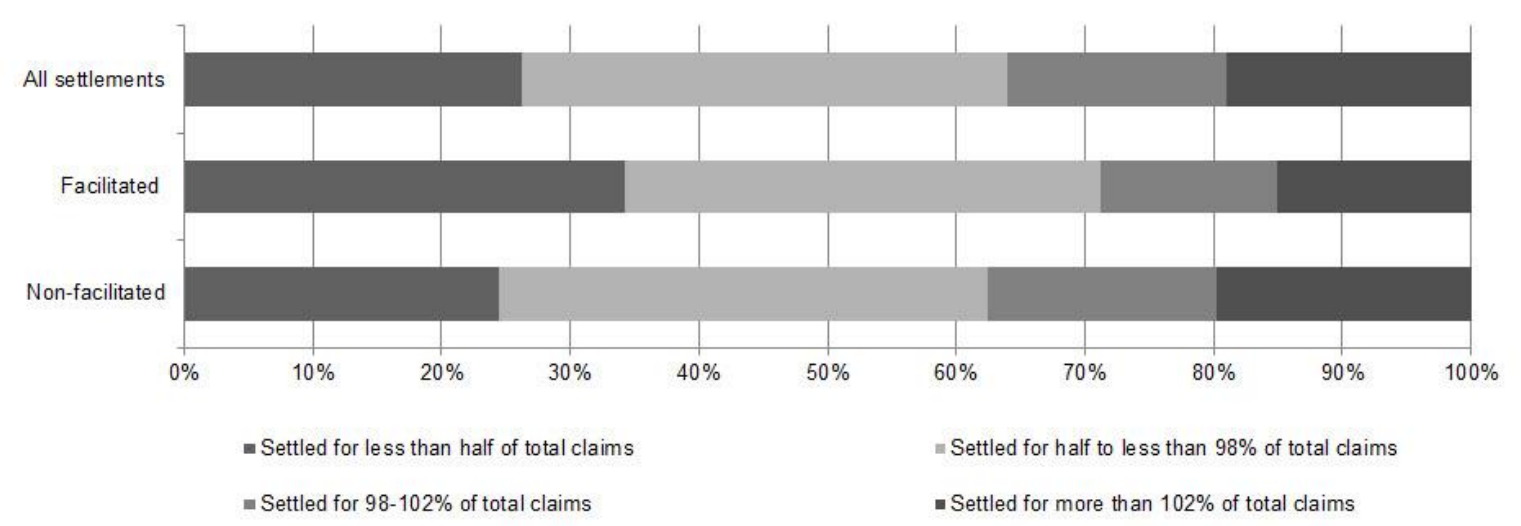

\section{Conclusion}

The compliance model is a prominent framework for the implementation of state regulation.

Recent reforms to ES enforcement in Ontario bear its influence. The MOL has sought to reduce the 'heavy hand' of the state in claims resolution, whether through the provision of more information to both employers and employees, a growing emphasis on self-help and selfregulation as the first step in claims resolution, or an emphasis on facilitated as well as nonfacilitated settlements which eschew the adjudication of legal entitlements. These developments are premised on a view that employees, as the desired beneficiaries of regulation, are able to assert their interests effectively, and that violations are relatively uncommon and result mainly from ignorance and incompetence of employers. At the same time, deterrence measures based on the notion that non-compliance is an intentional act involving an assessment of its costs and benefits, and which therefore imposes a punishment for violators, remain a residual feature of the Ontario's ES enforcement regime. Deterrence measures are reserved mainly for employers who not only violate the ESA, but ignore the authority of the state when it orders compliance.

Yet, evidence from complaints filed with the MOL paints a picture very much at odds with the assumptions of the compliance model. The administrative data provide several 
indications of employees' constrained ability to exercise voice when they believe they have experienced violations. The share of Ontario employees who come forward with a complaint has decreased in recent years, and less than 1 in 10 complainants remain on the job they are complaining about. Additionally, reprisal claims have increased in recent years, and a majority of complainants seeking an exemption to the self-help requirement indicate fear of their employer as the basis for their request. Complainants with claims for monetary ES violations are concentrated in industries and firms characterized by high rates of precarious employment, including accommodations and food services, support services and the construction industry as well as in small firms with less than 20 employees.

Administrative data on the features of validated monetary claims indicate that intentional, even egregious violations are much more common than the compliance framework acknowledges. Unpaid wages are the most common claim filed by complainants, and the median amount of validated entitlements are for high dollar amounts that represent a substantial portion of weekly or monthly earnings for low income earners. There are further indicators of employers' recalcitrance in the enforcement process. Employers are more likely to voluntarily comply with lower dollar value claims, and only a minority of monetary orders is fully satisfied.

The findings point toward the need for models of enforcement that are not premised on the initial assumption of unintentionality of violations, and the corresponding assumption that enforcement should always begin with education and other compliance measures and only escalate when those measures have failed, as is the case in Ayres and Braithwaite's enforcement pyramid. In light of changes to the organization of employment that deepen insecurity for employees and augment employer power, heavily reliance on compliance over deterrence is unlikely to effectively prevent or remedy ES violations. Effective, evidence-based workplace 
regulation requires enforcement models that recognize workplace power imbalances, and how different industries organize employment in ways that create pressures and opportunities for ES violations.

\section{NOTES}

${ }^{1}$ Monetary ES violations refer to the phenomenon of employees not being paid the wages and other monetary benefits to which they are legally entitled.

${ }^{2}$ For a discussion of similar problems in the US Department of Labor's Wage and Hour Division administrative database, as well as potential solutions, see Morantz (2014).

${ }^{3}$ There is a sharp distinction in Canada between regulatory offenses and crimes. Provinces can enact regulatory laws in respect of matters within their constitutional competence, which includes employment, and punish violators by fine and/or imprisonment. However, only the federal government has the constitutional authority to enact criminal laws. The difference between crimes and regulatory offenses is not just a matter of semantics because of the much greater social opprobrium that is attached to committing a crime as opposed to a regulatory offense.

${ }^{4}$ Employers operating in this environment may also be more ignorant and incompetent than those operating is less highly competitive environments.

${ }^{5}$ Following the budget cycle of the provincial government, the fiscal year runs from April 1 to March 31. 2014/15 is the most recent fiscal year for which outcome information is available for the majority of submitted complaints.

${ }^{6}$ Workers can also bring civil actions to enforce ESA claims on the theory that ESA obligations are implied terms of the contract of employment. Boland v. APV Canada Inc., 2005 CanLII 3384 (ON SCDC).

${ }^{7}$ Source: Complaints received from MOL (2006, 2014), non-unionized Ontario employees from Statistics Canada Labor Force Survey (2004-2014).

${ }^{8}$ Industry information is available for $95 \%$ of monetary ES complaints. Complaints that were withdrawn or settled are less likely to have industry information available than complaints with other outcomes.

${ }^{9}$ As firm size information is only available for $60 \%$ of monetary ES complaints, this analysis should be interpreted with caution. Nonetheless, it corresponds with the general trends related to firm size identified by the MOL in their reports.

${ }^{10}$ Among small and medium size businesses in Canada, only 62 percent survived for three years and 51 percent of firms survived for five years; survival rates are even lower among microenterprises (Industry Canada 2012, 2013).

${ }^{11}$ In this section, the analysis is limited to complaints that include monetary claims related to unpaid wages, overtime pay, vacation pay/time, public holiday pay, deductions/ temporary help agency (THA) fees, minimum wages, termination pay and severance pay (collectively referred to as monetary complaints).

${ }^{12}$ A complaint can include a claim relating to one or more employment standards.

${ }^{13}$ In this graph a $2 \%$ margin around the claim amount was allowed in order to accommodate inconsistent rounding and decimal use in the data, which resulted in many entitlements that had a \$1-2 difference from the claim amount. 


\section{REFERENCES}

Alexander C (2013) Anticipatory Retaliation, Threats, and the Silencing of the Brown Collar Workforce. American Business Law Journal 50, 779-834.

Almond P and Colover S. (2012) The Criminalization of Workplace Death. British Journal of Criminology 52: 997-1016.

Almond P and Gray GC. (Accepted Article) Frontline Safety: Understanding the Workplace as a Site of Regulatory Engagement. Law \& Policy.

Amengual M and Fine J (2016) Co-enforcing Labor Standards: The Unique Contributions of State and Worker Organizations in Argentina and the United States. Regulation and Governance (early view) DOI: $10.1111 /$ rego.12122

Ayres I and Braithwaite J (1992) Responsive Regulation: Transcending the Deregulation Debate. Oxford: Oxford University Press.

Bernhardt A, Spiller M and Polson D (2013) All Work and No Pay: Violations of Employment and Labor Laws in Chicago, Los Angeles and New York City. Social Forces 91(3): 725 746.

Davidov G (2010) The Enforcement Crisis in Labour Law and the Fallacy of Voluntarist Solutions. International Journal of Comparative Labour Law and Industrial Relations 26(1): 61-82.

Dickens L (2014) The Coalition Government's Reforms to Employment Tribunals and Statutory Employment Rights_-Echoes of the Past. Industrial Relations Journal 45:3, 234-249.

Employment Standards Work Group (1996) Bad Boss Stories: Workers Whose Bosses Break the Law. Toronto: ESWG.

Estlund C (2005) Rebuilding the Law of the Workplace in an Era of Self-Regulation. Columbia Law Review 105(2): 319-404.

Faraday F (2014) Profiting from the Precarious. How Recruitment Practices Exploit Migrant Workers. Metcalf Foundation. http://metcalffoundation.com/publicationsresources/view/profiting-from-the-precarious-how-recruitment-practices-exploit-migrantworkers/ [accessed March 04 2015].

Fine J (2013) Solving the Problem From Hell: Tripartism as a Strategy for Addressing Labor Standards Non-Compliance in the United States. Osgoode Hall Law Journal 50: 813-43.

Fudge J (1991) Labour Law's Little Sister: The Employment Standards Act and the Feminization of Labour. Ottawa: Canadian Centre for Policy Alternatives. 
Gray GC (2009) The Responsibilization Stragegy of Health and Safety. British Journal of Criminology 49: 326-342.

Griffith K (2015) Worker Centers and Labor Law Protections: Why Aren't They Having Their Cake? Berkeley Journal of Employment and Labor Law 36(2): 331-349.

Gunningham N (2010) "Enforcement and Compliance Strategies." In R Baldwin, M Cave and M Lodge (eds.), The Oxford Handbook of Regulation. Oxford: Oxford University Press: 120-145.

Harvey D (2005) A Brief History of Neoliberalism. New York: Oxford University Press.

Industry Canada (2012): https://www.ic.gc.ca/eic/site/061.nsf/vwapj/KSBS-PSRPE_JulyJuillet2012_eng.pdf/\$FILE/KSBS-PSRPE_July-Juillet2012_eng.pdf [accessed January 04 2016]

Industry Canada (2013): https://www.ic.gc.ca/eic/site/061.nsf/vwapj/KSBS-PSRPE_AugustAout2013_eng.pdf/\$FILE/KSBS-PSRPE_August-Aout2013_eng.pdf [accessed January 04 2016]

International Labour Organization (2006) Report III (Part IB) General Survey of the reports concerning the Labour Inspection Convention. International Labour Conference, $95^{\text {th }}$ Session, Geneva.

Judson T and Francisco-McGuire C (2012) Where Wage Theft is Legal: Mapping Wage Theft Laws in the 50 States. Progressive States Network. Online: https://stateinnovation.org/pubs/reports/where-theft-legal-mapping-wage-theft-laws-inthe-50-states [accessed March 03 2015].

Lewchuk W et al (2015) The Precarity Penalty: The Impact of Employment Precarity on Individuals, Households and Communities - and What Can be Done About It. Poverty and Employment Precarity in Southern Ontario.

Mascini P (2012) Why Was the Enforcement Pyramid So Influential? And What Price Was Paid? Regulation and Governance 7(1): 48-60.

Milkman, R, González, AL, Ikeler, P (2012) "Wage and Hour Violations in Urban Labour Markets: A Comparison of Los Angeles, New York and Chicago. Industrial Relations Journal 43:5, 378-398.

Ministry of Labour (2005) Historical Funding - Operations, 2004-05. [accessed April 16 2007].

Ministry of Labour (2015) Appendix: Annual Report 2014-15. https://www.labour.gov.on.ca/english/about/pubs/rbp/2015/rbp_8.php [accessed July 05 2016].

Ministry of Labour (Undated) Administrative Manual for Employment 
Standards. Chapter 5 - Appendix - Procedures for s. 101.1 Facilitated Settlements.

Morantz A (2014) Putting Data to Work for Workers: The Role of Information

Technology in U.S. Worker Protection Agencies. ILR Review 67 Supplement, 675701.

Noack AM and Vosko LF (2011) Precarious Jobs in Ontario: Mapping Dimensions of Labour Market Insecurity by Workers' Social Location and Context. Online: http://www.lco-cdo.org/vulnerable-workers-commissioned-papers-vosko-noack.pdf [accessed September 03 2015].

Noack AM, Vosko LF and Grundy J (2015) Measuring Employment Standards Violations, Evasion and Erosion - Using a Telephone Survey. relations industrielles Industrial Relations 70-1: 78-101.

Office of the Provincial Auditor of Ontario (2004) 2004 Annual Report of the Provincial Auditor of Ontario, VFM Section 3.09, Employment Rights and Responsibilities Program, Online: http://www.auditor.on.ca/)en/reports_en/en04/309en04. pdf [accessed 9 February 2014].

Pearce, F and Tombs S (1990) Ideology, Hegemony, and Empiricism. British Journal of Criminology 30: 423-443

Reiss, A.J. (1984) Selecting Strategies of Social Control over Organizational Life in K Hawkins and JM Thomas, Enforcing Regulation Boston: Kluwer: 23-35.

Reynaers, A-M and Parrado S (2016) Responsive Regulation in Public-Private Partnerships: Between Deterrence and Persuasion Regulation and Governance (early view) doi:10.111/rego. 12121.

Ruckelshaus C (2008) Labor’s Wage War. Fordham Urban Law Journal 35(2), 373-407.

Shamir R (2010) Capitalism, Governance, and Authority: The Case of Corporate Social Responsibility. The Annual Review of Law and Social Science 6: 531-553.

Thomas MP (2009) Regulating Flexibility: The Political Economy of Employment Standards. Montreal and Kingston: McGill-Queen's University Press.

Tombs S and Whyte D (2010) A Deadly Consensus: Regulatory Degradation under New Labour. British Journal of Criminology 50: 46-64.

Tombs S and Whyte D (2013) Transcending the Deregulation Debate? Regulation, Risk, and the Enforcement of Health and Safety Law in the UK. Regulation and Governance 7(1): 61-79.

Tombs S and Whyte D (2013a) The Myths and Realities of Deterrence in Workplace Safety Regulation. British Journal of Criminology 53: 746-763. 
Tucker E (2013) Old Lessons for New Governance: Safety or Profit and the New Conventional Wisdom. In Nichols T and Walters D (eds.), Safety or Profit: International Studies in Governance, Change and the Work Environment. New York: Baywood Press: 71-95.

Tucker E (2016) When Wage Theft Was a Crime. Paper Prepared for Law/Authority/History: Honouring the Voice of Douglas Hay, York University, May 5-6, 2016.

Vézina M, Cloutier E, Stock S, Lippel K, Fortin É, Delisle A, St-Vincent M, Funes A, Duguay P, Vézina S, Prud'homme P (2011) Summary Report. Québec Survey on Working and Employment Conditions and Occupational Health and Safety (EQCOTESST), Québec, Institut de recherche Robert-Sauvé en santé et sécurité du travail, Institut national de santé publique du Québec and Institut de la statistique du Québec.

Vosko LF, Grundy J and Thomas MP (2016) Challenging New Governance: Evaluating New Approaches to Employment Standards Enforcement in Common Law Jurisdictions. Economic and Industrial Democracy 37(2): 373-398

Weil D (2010) Improving Workplace Conditions Through Strategic Enforcement: A Report to the Wage and Hour Division. Boston, Mass.: Boston University.

Weil D (2014) The Fissured Workplace: Why Work Became So Bad for So Many and What Can Be Done to Improve It. Cambridge: Harvard University Press.

Weil D and Pyles A (2006) Why Complain? Complaints, Compliance, and the Problem of Enforcement in the U.S. Workplace. Comparative Labour Law and Policy Journal 27, 59-92.

Wright, EO (2015) Understanding Class. London: Verso Press. 